\title{
Fruit yield and quality of sweet oranges affected by nitrogen, phosphorus and potassium fertilization in tropical soils
}

\author{
José Antônio QuAggıo ${ }^{a^{*}}$, Dirceu MATTos Jr. ${ }^{b}$, Heitor CANTARELLA ${ }^{a}$
}

\author{
${ }^{a}$ Centro de Pesquisa e \\ Desenvolvimento de Solos e \\ Recursos Ambientais, Instituto \\ Agronômico (IAC), \\ Av. Barão de Itapura 1481, \\ CEP 13020-902 Campinas \\ (SP), Brazil \\ quaggio@iac.sp.gov.br \\ ${ }^{b}$ Centro Avançado de \\ Pesquisa Tecnológica do \\ Agronegócio de Citros "Sylvio \\ Moreira", Instituto Agronômico \\ (IAC), Rod. Anhanguera km \\ 158, CEP 13490-970 \\ Cordeirópolis (SP), Brazil
}

${ }^{*}$ Correspondence and reprints

Received 18 July 2005 Accepted 13 April 2006

Fruits, 2006, vol. 61, p. 293-302 (c) 2006 Cirad/EDP Sciences All rights reserved DOI: 10.1051 /fruits:2006028 www.edpsciences.org/fruits

RESUMEN ESPAÑOL, p. 302
Fruit yield and quality of sweet oranges affected by nitrogen, phosphorus and potassium fertilization in tropical soils.

Abstract - Introduction. The objective of the present paper was to evaluate the effects of $\mathrm{N}, \mathrm{P}$ and $\mathrm{K}$, and their interactions, on fruit yield and quality of two sweet orange varieties, Valencia and Pêra, grown on tropical soils in the State of São Paulo, Brazil, over four seasons. Materials and methods. Two experiments were set up in a fractional factorial design of the $1 / 2(4 \times 4 \times 4)$ type, with four rates of $\mathrm{N}\left[(30,100,170\right.$ and 240$\left.) \mathrm{kg}^{-1} \mathrm{ha}^{-1} \cdot \mathrm{year}^{-1}\right], \mathrm{P}[(9,27,45$ and 63) $\left.\left.\mathrm{kg} \cdot \mathrm{ha}^{-1} \cdot \mathrm{year}^{-1}\right)\right]$ and $\mathrm{K}\left[\left(24,91,158\right.\right.$ and 225) $\left.\mathrm{kg} \cdot \mathrm{ha}^{-1} \cdot \mathrm{year}^{-1}\right]$ applied to the soil surface during the rainy season. Functions of the type $y=b_{O}+b_{11} \mathrm{~N}+b_{11} \mathrm{~N}^{2}+b_{2} \mathrm{P}+b_{22} \mathrm{P}^{2}+$ $b_{3} \mathrm{~K}+b_{33} \mathrm{~K}^{2}+b_{12} \mathrm{NP}+b_{13} \mathrm{NK}+b_{23} \mathrm{PK}$ were fitted for dependent variables: fruit yield and mass, juice content, and total soluble solids and acidity concentrations. Results. Maximum yield of Pêra and Valencia was attained, respectively, with $\mathrm{N}$ rates of (189 and 193) $\mathrm{kg} \cdot \mathrm{ha}^{-1}$. Fruit yield response to $\mathrm{P}$ and $\mathrm{K}$ fertilization for both cultivars was dependent on soil nutrient availability. Fruit size of Valencia trees was markedly affected by rates of K over $225 \mathrm{~kg} \cdot \mathrm{ha}^{-1}$. Yield of soluble solids per box of fruits $(40.8 \mathrm{~kg})$ decreased as leaf $\mathrm{K}$ concentration varied from (10 to 12) $\mathrm{g} \cdot \mathrm{kg}^{-1}$. Conclusion. Soil testing and leaf analysis play an important role in defining fruit yield and quality for citrus trees. The best nutritional program may vary depending on the destination of fruit to either juice production or the fresh market.

Brazil / Citrus sinensis / nutritional requirements / fertilizer application / application rates / yields / quality / fruits

Effets de la fertilisation en azote, phosphore et potassium sur le rendement et la qualité des oranges produites sur sols tropicaux.

Résumé - Introduction. L'objectif de nos travaux a été d'évaluer les effets de N, P et K, et leurs interactions, sur le rendement et la qualité des fruits de deux variétés d'orangers, Valencia et Pêra, développés sur sols tropicaux dans l'État de São Paulo, Brésil, pendant quatre saisons de production. Matériel et méthodes. Deux expérimentations ont été menées selon un plan factoriel partiel du type $1 / 2(4 \times 4 \times 4)$, avec quatre doses de $\mathrm{N}[(30,100,170$ et 240) $\left.\mathrm{kg} \cdot \mathrm{ha}^{-1} \cdot \mathrm{an}^{-1}\right]$, P $\left[\left(9,27,45\right.\right.$ et 63) $\mathrm{kg} \cdot \mathrm{ha}^{-1} \cdot \mathrm{an}^{-1}$ ] et $\mathrm{K}\left[\left(24,91,158\right.\right.$ et 225) $\mathrm{kg} \cdot \mathrm{ha}^{-1} \cdot \mathrm{an}^{-1}$ ] appliquées à la surface de sol pendant la saison des pluies. Des fonctions du type $y=b_{O}+$ $b_{11} \mathrm{~N}+b_{11} \mathrm{~N}^{2}+b_{2} \mathrm{P}+b_{22} \mathrm{P}^{2}+b_{3} \mathrm{~K}+b_{33} \mathrm{~K}^{2}+b_{12} \mathrm{NP}+b_{13} \mathrm{NK}+b_{23} \mathrm{PK}$ ont été adaptées à des variables dépendantes : rendement et masse de fruit, contenu en jus, teneurs en solides solubles totaux et en acidité. Résultats. Les meilleurs rendements de Pêra et de Valencia ont été atteints avec des doses respectives de (189 et 193) $\mathrm{kg} \mathrm{N} \cdot \mathrm{ha}^{-1}$. Pour cette même variable, la réponse à la fertilisation de ces deux cultivars avec $\mathrm{P}$ et $\mathrm{K}$ a dépendu de la disponibilité en éléments nutritifs de sol. Le calibre des fruits de Valencia a été nettement affecté par des doses de $\mathrm{K}$ supérieures à $225 \mathrm{~kg} \cdot \mathrm{ha}^{-1}$. Le rendement en solides solubles par boîte de fruits $(40,8 \mathrm{~kg})$ a diminué en même temps que la teneur en $\mathrm{K}$ des feuilles variait de (10 à 12) $\mathrm{g} \cdot \mathrm{kg}^{-1}$. Conclusion. Les analyses de sols et de feuilles ont un rôle déterminant sur la définition du rendement et de la qualité des agrumes. Les programmes nutritionnels optimaux peuvent varier selon que la récolte est destinée à l'industrie du jus ou au marché du fruit frais.

Brésil / Citrus sinensis / besoin nutritionnel / fertilisation / dose d'application / rendement / qualité / fruits 


\section{Introduction}

The Brazilian citrus industry produced 14.7 Mt of oranges in the 2003-2004 season. A third part of this total amount was destined for the fresh fruit market and the majority for frozen concentrate orange juice production.

Juice content, total soluble solids and acidity are the most important fruit traits for frozen concentrate orange juice processing, while fruit size, and peel texture and color, are valuable for the fresh market because consumers require fruit with superior external characteristics. These characteristics depend on scion and rootstock combinations, and vary from season to season due to climate and crop management conditions, such as irrigation and nutrient supply [1].

Effects of fertilization on orange fruit quality were investigated mostly in Florida during the 1950s and 1960s. Results published from these studies failed to establish defined trends for nutrient supply due to fruit load of trees, year-to-year climate variations, and differential scion and rootstock responses. Stewart et al. [2], Stewart and Wheaton [3] and Koo [4] observed that total soluble solids (TSS) content of Valencia and Pineapple sweet oranges increased as the nitrogen $(\mathrm{N})$ rate increased, while Reitz and Koo [5] and Smith et al. [6] observed opposite trends. These differences might be related to varietal responses, as demonstrated by the work of Deszyck et al. [7], in which TSS content of Valencia decreased and that of Hamlin increased as the potassium $(\mathrm{K})$ rates increased. Reese and Koo [8, 9] reported, from data collected in a $\mathrm{N} \times \mathrm{K}$ factorial experiment, that soluble solids content of oranges varied as $\mathrm{N}$ rates increased. Nitrogen fertilization promoted a decrease in this characteristic during off-year crops and the opposite during on-year crops.

Other research results have been published demonstrating a strong relationship between fruit quality and $\mathrm{K}$ availability. Potassium rates increase fruit size and total juice acidity, and decrease the ratio of sev-

\footnotetext{
${ }^{1}$ http://www.abecitrus.com.br/english/ producao_us.html (March 2006).
}

eral citrus varieties. On the other hand, $\mathrm{K}$ rates decrease the soluble solids content of juice because of increased peel thickness [4, 7-11]. The effect of $\mathrm{N}$ rates decreasing fruit size was reported for oranges [5].

Fruit yield and quality of citrus are greatly influenced by $\mathrm{N}$ and $\mathrm{K}$ supplies in tropical soils because these nutrients are subjected to losses in the environment [12] and are the ones most exported by citrus fruits [13]. Therefore, attention should be paid to establishing nutrient management strategies to improve growers' profitability.

The effect of phosphorus (P) fertilization on fruit quality appears to be less clear, even though a decrease in soluble solids content and total acidity was associated with $\mathrm{P}$ supply $[14,15]$. This was more pronounced during heavy crop years.

The objective of the present paper was to evaluate the effects of $\mathrm{N}, \mathrm{P}$ and $\mathrm{K}$, and their interactions, on fruit yield and quality of two orange varieties grown on tropical soils in the field and conducted during longterm experimentation.

\section{Materials and methods}

Two long-term experiments were carried out over 6 years in commercial citrus orchards in two different locations of the State of São Paulo, Brazil (table I). In both sites, soil acidity was corrected by lime application every 3 to 4 years in order to maintain soil base saturation within the range of (50 to 70)\%. Soil $\mathrm{P}$ availability was low in Matão and high in Pirassununga, whereas exchangeable $\mathrm{K}$ was medium in Matão and low in Pirassununga, according to present soil testing interpretation in the State of São Paulo [16].

The experiment in Matão was set up in a grove of Valencia sweet orange [Citrus sinensis (L.) Osbeck] on Rangpur lime (C. limonia Osbeck), spaced $8 \mathrm{~m} \times 6 \mathrm{~m}$ and planted in 1981. In Pirassununga, the grove was planted with Pêra [C. sinensis (L.) Osbeck] sweet orange on Cleopatra mandarin [C. reshni (Hayata) hort. ex. Tanaka] at $7.5 \mathrm{~m} \times 4.0 \mathrm{~m}$, in 1984. Both experiments 
Table I.

Soil characteristics at the $0-20 \mathrm{~cm}$ layer of two different sites of the State of São Paulo, Brazil, where commercial citrus groves were studied.

\begin{tabular}{lcccccccc} 
Site & Soil type & $\mathrm{pH}\left(\mathrm{CaCl}_{2}\right)$ & $\begin{array}{c}\text { Organic matter } \\
\left(\mathrm{g} \cdot \mathrm{dm}^{-3}\right)\end{array}$ & $\begin{array}{c}\text { P-resin } \\
\left(\mathrm{mg} \cdot \mathrm{dm}^{-3}\right)\end{array}$ & $\begin{array}{c}\text { Exchangeable cations } \\
\left(\mathrm{mmol}_{\mathrm{c}} \cdot \mathrm{dm}^{-3}\right)\end{array}$ & $\begin{array}{c}\text { Soil base saturation } \\
(\%)\end{array}$ \\
& & & & & $\mathrm{Ca}$ & $\mathrm{Mg}$ & $\mathrm{K}$ & \\
\hline Matão & Ultisol & 5.6 & 16 & 9 & 22 & 9 & 2.9 & 64 \\
Pirassununga & Oxissol & 5.8 & 15 & 45 & 26 & 8 & 1.2 & 71
\end{tabular}

were conducted without irrigation. Average annual rainfall for both sites is $1350 \mathrm{~mm}$. Drought periods may occur during the winter in these locations. Experimental plots consisted of four rows with five uniform trees per row, a total of 20 trees per plot. The six central trees within plots were used for sampling.

Treatments were set up in a fractional factorial design of the $1 / 2(4 \times 4 \times 4)$ type. Therefore, experiments consisted of only a fraction of the complete factorial combinations, summing 32 treatments per site without replication and divided into two blocks, proposed by Colwell [17] and adapted by Andrade and Noleto [18]. Confounding of unlike treatment effects was used to reduce the size of the experiment, increasing the efficiency of the model to measure meaningful effects. Rates of $\mathrm{N}[(30,100,170$ and 240) $\mathrm{kg} \cdot \mathrm{ha}^{-1} \cdot \mathrm{year}^{-1}$ ], as ammonium nitrate, $\mathrm{P}\left[\left(9,27,45\right.\right.$ and 63) $\left.\mathrm{kg} \cdot \mathrm{ha}^{-1} \cdot \mathrm{year}^{-1}\right]$, as triple superphosphate, and K [ $(25,91,157$ and 223) $\mathrm{kg} \cdot \mathrm{ha}^{-1} \cdot \mathrm{year}^{-1}$ ], as potassium chloride, were tested. Fertilizer amounts from each treatment were mixed and applied to the soil surface in three split applications, on both sides of trees (in bands $150 \mathrm{~cm}$ wide and $50 \mathrm{~cm}$ away from the tree trunk), from early spring to late summer. Zinc, manganese and boron were applied by foliar spray three times a year.

Fruit yield was measured annually by summing the weight of fruit, if more than one harvest per year was done. Fruit samples $(n=15)$ were collected at maturation. Fresh mass of fruits and percent juice content (based on mass fraction) were evaluated as well as juice quality, by determining total soluble solids (TSS) and acidity [19]. The amounts of TSS content per orange box $(40.8 \mathrm{~kg})$ and per area were calculated.

Soil and leaf samples were collected every two years. Soil samples were taken from both the $0-20 \mathrm{~cm}$ and $20-40 \mathrm{~cm}$ depth layers and analyzed according to the methods described by Raij et al. [20]. Four- to sixmonth-old spring flush leaves were sampled from fruiting terminals and analyzed for total nutrient concentrations, according to Bataglia et al. [21].

Statistical procedures were based on analysis of variance. Data for selected variables averaged over four seasons were fitted using the model: $y=b_{0}+b_{11} \mathrm{~N}+b_{11} \mathrm{~N}^{2}+$ $b_{2} \mathrm{P}+b_{22} \mathrm{P}^{2}+b_{3} \mathrm{~K}+b_{33} \mathrm{~K}^{2}+b_{12} \mathrm{NP}+$ $b_{13} \mathrm{NK}+b_{23} \mathrm{PK}$, where $b_{0}=$ overall constant, $b_{1}=$ constant for the linear component of $\mathrm{N}$ effect, $b_{11}=$ constant for the quadratic component of $\mathrm{N}$ effect, $b_{2}=$ constant for the linear component of $\mathrm{P}$ effect, $b_{22}=$ constant for the quadratic component of $\mathrm{P}$ effect, $b_{3}=$ constant for the linear component of $\mathrm{K}$ effect, $b_{33}=$ constant for the quadratic component of $\mathrm{N}$ effect, $b_{12}=$ constant for the $\mathrm{N} \times \mathrm{P}$ interaction, $b_{13}=$ constant for the $\mathrm{N} \times \mathrm{K}$ interaction, $b_{23}=$ constant for the $\mathrm{P} \times \mathrm{K}$ interaction. If, for example, one nutrient did not significantly affect the dependent variable, it was held constant so that the model could be simplified as a response function for two nutrients. The model chosen encompasses the most significant effects expected in biological science, i.e., linear and quadratic effects for each nutrient and linear $\times$ linear interactions between nutrients. Rates of nutrients for optimum fruit yield and quality were estimated by applying differential calculus to response models 
Table II.

Effects of N, P and K on fruit yield and quality of Pêra sweet orange trees in Pirassununga (State of São Paulo, Brazil). Data represent average of four seasons.

\begin{tabular}{|c|c|c|c|c|c|c|c|}
\hline $\begin{array}{l}\text { Nutrient rate } \\
\left(\mathrm{kg}^{-} \mathrm{ha}^{-1} \cdot \text { year }^{-1}\right)\end{array}$ & $\begin{array}{c}\text { Fruit } \\
\text { yield } \\
\left(\mathrm{t} \cdot \mathrm{ha}^{-1}\right)\end{array}$ & $\begin{array}{l}\text { Juice } \\
\text { content } \\
(\%)\end{array}$ & $\begin{array}{c}\text { Total soluble } \\
\text { solids (TSS) } \\
{ }^{\circ} \text { Brix }\end{array}$ & $\begin{array}{l}\text { Acidity } \\
(\%)\end{array}$ & $\begin{array}{l}\text { Fruit mass } \\
\text { (g) }\end{array}$ & $\begin{array}{l}\text { TSS per box } \\
(\mathrm{kg})\end{array}$ & $\begin{array}{l}\text { TSS per area } \\
\left(\mathrm{kg}^{\prime} \mathrm{ha}^{-1}\right)\end{array}$ \\
\hline \multicolumn{8}{|l|}{ Nitrogen (N) } \\
\hline 30 & 30.4 & 56.5 & 11.4 & 0.81 & 177 & 2.61 & 1935 \\
\hline 100 & 36.7 & 56.4 & 11.2 & 0.78 & 169 & 2.56 & 2305 \\
\hline 170 & 41.1 & 55.5 & 11.0 & 0.77 & 170 & 2.49 & 2502 \\
\hline 240 & 40.4 & 55.2 & 11.0 & 0.79 & 167 & 2.48 & 2452 \\
\hline \multicolumn{8}{|l|}{ Phosphorus (P) } \\
\hline 9 & 37.3 & 56.0 & 11.2 & 0.80 & 169 & 2.55 & 2324 \\
\hline 27 & 37.7 & 55.9 & 11.1 & 0.79 & 171 & 2.51 & 2317 \\
\hline 45 & 37.0 & 55.9 & 11.1 & 0.76 & 175 & 2.51 & 2267 \\
\hline 63 & 36.6 & 55.8 & 11.2 & 0.78 & 168 & 2.56 & 2282 \\
\hline \multicolumn{8}{|l|}{ Potassium (K) } \\
\hline 25 & 33.3 & 56.2 & 11.5 & 0.76 & 159 & 2.60 & 2106 \\
\hline 91 & 38.0 & 56.4 & 11.0 & 0.79 & 172 & 2.55 & 2380 \\
\hline 157 & 38.4 & 55.4 & 11.0 & 0.78 & 176 & 2.48 & 2324 \\
\hline 223 & 38.8 & 55.7 & 11.0 & 0.82 & 176 & 2.42 & 2382 \\
\hline Significance ${ }^{1}$ & $\begin{array}{l}\mathrm{N}_{\mathrm{L}}{ }^{\star *} \\
\mathrm{~N}_{\mathrm{Q}^{*}} \\
\mathrm{~K}_{\mathrm{L}}^{\star \star}\end{array}$ & $\begin{array}{c}\mathrm{N}_{\mathrm{L}^{*}} \\
\mathrm{NP} \mathrm{L}^{*}\end{array}$ & $\begin{array}{l}\mathrm{N}_{\mathrm{L}}{ }^{*} \\
\mathrm{~K}_{\mathrm{L}}^{*}\end{array}$ & $\begin{array}{l}\mathrm{P}_{\mathrm{Q}^{*}} \\
\mathrm{~K}_{\mathrm{L}}{ }^{*}\end{array}$ & $\begin{array}{l}\mathrm{N}_{\mathrm{L}^{*}} \\
\mathrm{~K}_{\mathrm{L}}^{*}\end{array}$ & $\begin{array}{l}\mathrm{N}_{\mathrm{L}}^{*} \\
\mathrm{~K}_{\mathrm{L}}^{*}\end{array}$ & $\mathrm{~N}_{\mathrm{L}}{ }^{*}$ \\
\hline $\begin{array}{l}\text { Coefficient } \\
\text { of variation (\%) }\end{array}$ & 8.7 & 2.2 & 2.2 & 4.8 & 3.3 & 3.8 & 10.0 \\
\hline \multicolumn{8}{|l|}{$\begin{array}{l}\text { Box }=40.8 \mathrm{~kg} . \\
{ }^{1} \text { Subscript L an }\end{array}$} \\
\hline
\end{tabular}

as follows: $[\mathrm{dY} / \mathrm{dX}]=0$, where $\mathrm{Y}=$ dependent variable and $\mathrm{X}=$ nutrient $\mathrm{N}, \mathrm{P}$ or $\mathrm{K}$.

\section{Results and discussion}

\subsection{Nitrogen effects}

A positive response of $\mathrm{N}$ fertilization was observed in Pirassununga, where the average fruit yield for four harvests of Pêra sweet orange increased by $33 \%$ with an increase in $\mathrm{N}$ fertilization from (30 to 240 ) $\mathrm{kg} \cdot \mathrm{ha}^{-1}$ (table II). Fruit yield of Valencia trees, averaged for four harvests, increased by $10 \%$ for yield levels above $40 \mathrm{t} \cdot \mathrm{ha}^{-1}$ across the same tested nutrient rates for Pêra (table III).
Maximum yield of Pêra and Valencia estimated using equations (table IV) were attained with $\mathrm{N}$ rates of (189 and 193) $\mathrm{kg} \cdot \mathrm{ha}^{-1}$, respectively (table $\mathrm{V}$ ). Reese and KoO $[8,9]$ observed that yield of Hamlin, Pineapple and Valencia sweet oranges on Rough lemon rootstock were maximized at a $\mathrm{N}$ rate of $202 \mathrm{~kg} \cdot \mathrm{ha}^{-1}$. In the present study, Pêra was grafted on Cleopatra mandarin while Valencia was grafted on Rangpur lime rootstock, therefore the greater response to $\mathrm{N}$ fertilization could be related to the differential nutrient demand of rootstock varieties, as recently reported [22, 23]. Mattos Jr. [22] demonstrated that $\mathrm{N}$ response of sweet orange trees on Cleopatra was significantly greater than those on Rangpur lime. The latter rootstock is considered more 
Table III.

Effects of N,P and K on fruit yield and quality of Valencia sweet orange trees in Matão (State of São Paulo, Brazil). Data represent average of four seasons.

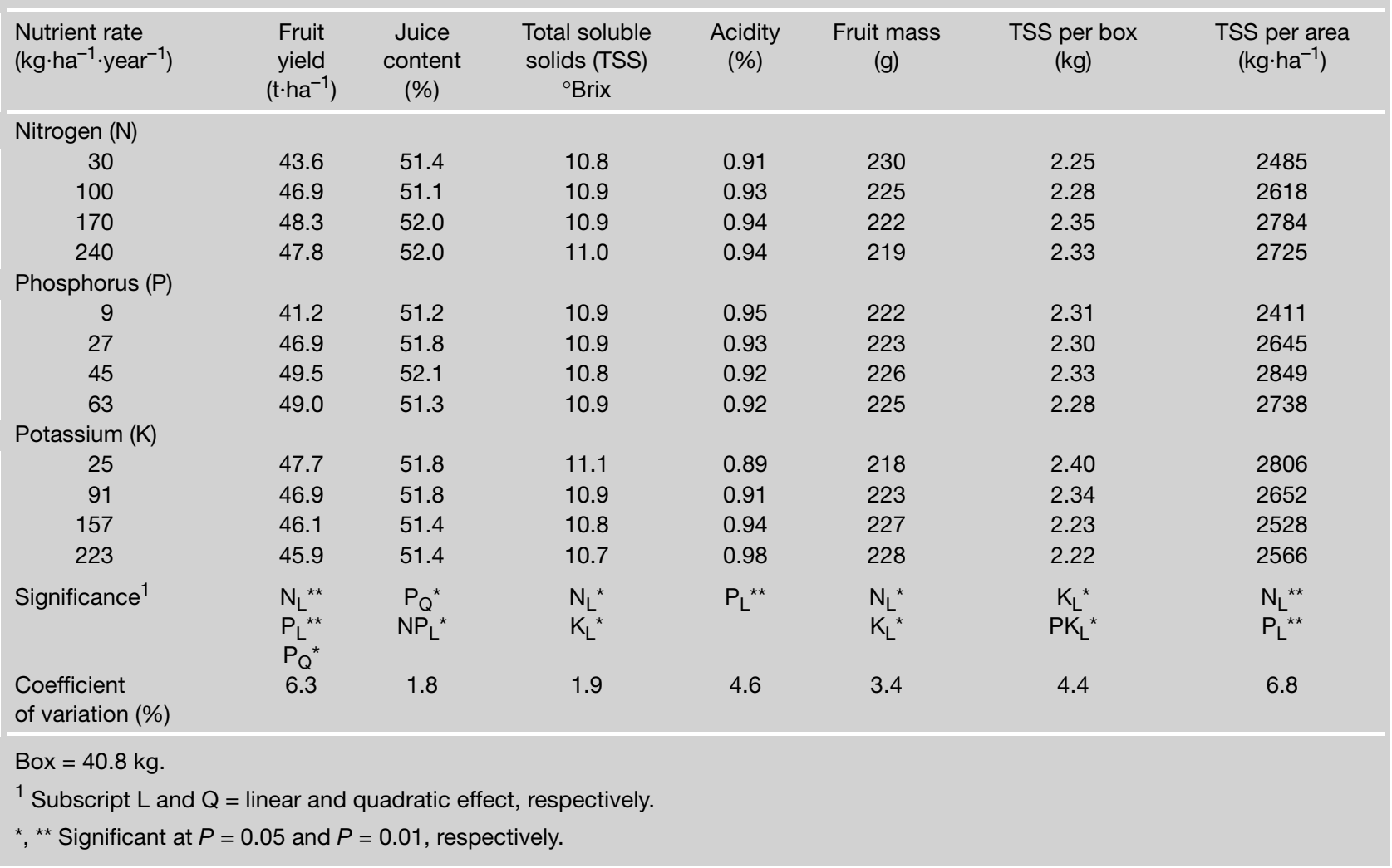

\section{Table IV.}

Simplified fertilizer response models for selected variables, for two sweet orange varieties.

Data represent average of four seasons.

\begin{tabular}{|c|c|c|c|c|c|c|c|}
\hline \multirow{2}{*}{$\begin{array}{l}\text { Dependent variable } \\
\text { Pêra }\end{array}$} & \multicolumn{6}{|c|}{ Response model ${ }^{1}$} & \multirow[t]{2}{*}{$\mathrm{R}^{2}$} \\
\hline & & & & & & & \\
\hline Yield $\left(\mathrm{t} \cdot \mathrm{ha}^{-1}\right)$ & 28.1 & $0.0971 \mathrm{~N}$ & $-0.000238 N^{2}$ & $0.0752 \mathrm{~K}$ & $-0.0003 K^{2}$ & $-0.00006 \mathrm{NK}$ & $0.72^{\star \star}$ \\
\hline Fruit mass (g) & 164.3 & $-0.1269 \mathrm{~N}$ & $0.000278 \mathrm{~N}^{2}$ & $0.2728 \mathrm{~K}$ & $-0.0008 K^{2}$ & $-0.00023 \mathrm{NK}$ & $0.63^{\star \star}$ \\
\hline Total soluble solids per box (kg) & 2.9 & $-0.0020 \mathrm{~N}$ & $0.000003 \mathrm{~N}^{2}$ & $-0.0025 \mathrm{~K}$ & $0.0000 \mathrm{~K}^{2}$ & $0.00001 \mathrm{NK}$ & $0.44^{\star *}$ \\
\hline Total soluble solids per ha $(\mathrm{kg})$ & 2038.0 & $5.5080 \mathrm{~N}$ & $-0.015023 N^{2}$ & $2.7165 \mathrm{~K}$ & $-0.0114 K^{2}$ & $-0.00300 \mathrm{NK}$ & $0.51^{*}$ \\
\hline \multicolumn{8}{|l|}{ Valencia } \\
\hline Yield $\left(t \cdot h a^{-1}\right)$ & 41.0 & $0.0398 \mathrm{~N}$ & $-0.000110 N^{2}$ & $0.4596 \mathrm{P}$ & $-0.0045 P^{2}$ & 0.00005 PK & $0.65^{\star *}$ \\
\hline Fruit mass (g) & 226.1 & $-0.1596 \mathrm{~N}$ & $0.000179 \mathrm{~N}^{2}$ & $0.1060 \mathrm{~K}$ & $-0.0003 K^{2}$ & $0.00014 \mathrm{NK}$ & $0.62^{\star \star}$ \\
\hline Total soluble solids per box (kg) & 2.4 & $-0.0001 N$ & $-0.000034 N^{2}$ & $-0.0011 P$ & $0.0000 P^{2}$ & $0.00003 \mathrm{PK}$ & $0.32^{*}$ \\
\hline Total soluble solids per ha $(\mathrm{kg})$ & 2272.2 & $3.0423 \mathrm{~N}$ & $-0.006505 N^{2}$ & $28.8562 \mathrm{P}$ & $-0.3209 P^{2}$ & -0.01572 PK & $0.52^{\star \star}$ \\
\hline \multicolumn{8}{|l|}{$\mathrm{Box}=40.8 \mathrm{~kg}$} \\
\hline
\end{tabular}


Table V.

Nutrient rates for maximum response of selected variables based on estimates obtained with simplified response models. Data represent average of four seasons.

\begin{tabular}{|c|c|c|c|}
\hline \multirow[t]{2}{*}{ Dependent variable } & \multicolumn{3}{|c|}{ Nutrient rate $\left(\mathrm{kg} \cdot \mathrm{ha}^{-1} \cdot\right.$ year $\left.^{-1}\right)$} \\
\hline & $\mathrm{N}$ & $P$ & $\mathrm{~K}$ \\
\hline \multicolumn{4}{|l|}{ Pêra } \\
\hline Yield (t.ha $\left.{ }^{-1}\right)$ & 189 & 9 & 124 \\
\hline Fruit mass $(g)$ & $240+$ & 9 & 127 \\
\hline Total soluble solids per box (kg) & $240+$ & 9 & 155 \\
\hline Total soluble solids per ha $(\mathrm{kg})$ & 174 & 9 & 97 \\
\hline \multicolumn{4}{|l|}{ Valencia } \\
\hline Yield $\left(\mathrm{t} \cdot \mathrm{ha}^{-1}\right)$ & 193 & 52 & 24 \\
\hline Fruit mass (g) & $240+$ & 9 & $225+$ \\
\hline Total soluble solids per box (kg) & 100 & 81 & 224 \\
\hline Total soluble solids per ha $(\mathrm{kg})$ & 185 & 40 & 24 \\
\hline
\end{tabular}

Box $=40.8 \mathrm{~kg}$.

Positive sign (+) indicates that maximum value for the dependent variable is attained at rates above the tested range. drought-resistant and more efficient at using nutrients than the former [23, 24]. Probably the rootstock plays a more major role in determining the response of citrus trees to $\mathrm{N}$ fertilization than orange cultivars.

Individual mass of fruits decreased with increased $\mathrm{N}$ rates for both varieties (tables I, II). This characteristic was also inversely correlated with total fruit yield because increasing the $\mathrm{N}$ rate increases fruit set of citrus trees and, consequently, the number of fruits produced per canopy volume unit. Goldschmidt and Monselise [25] demonstrated that mass of oranges, grapefruits and mandarins is inversely related to the total number of fruits per tree.

Total soluble solids (TSS) and juice percentage varied between the orange varieties. These variations were more prominent in Pêra than in Valencia, which is probably related to fruit size, normally larger in the latter than in the former variety. Usually, TSS and juice percentage decrease as fruit size increases (figure 1), due to the effect on fruit peel, which becomes thicker. For this reason, as $\mathrm{N}$ supply favors fruit set and reduces its size, we observed an increase in TSS and juice content of fruits $[11,26]$.
In our study, despite $\mathrm{N}$ rates reducing the fruit mass of Pêra variety fruits from (177 to 167) g (table II), it also promoted an unexpected decrease in TSS and juice content. Therefore, the increments in yield of total solids per area were related only to increments in fruit yield (table II).

For Valencia sweet orange, $\mathrm{N}$ rates decreased fruit mass from (230 to 219) $\mathrm{g}$ (table III), which resulted in increased TSS and juice content of fruits. Nitrogen promoted an accentuated increase in yield of soluble solids per area due to either increased fruit yield or improved fruit characteristics such as juice content and TSS (table III).

\subsection{Phosphorus effects}

Fruit yield response for both orange cultivars to $\mathrm{P}$ fertilization was dependent on the soil nutrient availability. No significant response to $\mathrm{P}$ was observed in Pirassununga (table II), where the soil was high in labile $\mathrm{P}\left(45 \mathrm{mg} \cdot \mathrm{dm}^{-3}\right)$ at the $0-20 \mathrm{~cm}$ layer. On the other hand, in Matão, where soil P was low $\left(9 \mathrm{mg} \cdot \mathrm{dm}^{-3}\right)$ at the same depth layer, fruit yield increased linearly with P fertilization.

Despite the accumulation of $\mathrm{P}$ in the soils during four years of fertilizer application (data not shown), maximum yield of Valencia in Matão was attained with a $\mathrm{P}$ rate of $52 \mathrm{~kg} \cdot \mathrm{ha}^{-1}$ (table IV). In general, the response of citrus to $\mathrm{P}$ has not been widely observed in temperate regions due to either high availability of this nutrient in native soil [14] or excess application of phosphate fertilizers over the years [11, 27]. The response of citrus to $P$ has been more frequent in tropical and subtropical soils, which are inherently very low or low in soil P $[22,28,30]$; it can be predicted by the soil-testing calibration curve proposed by Quaggio et al. [16], in which the critical P-resin level in surface soil is $20 \mathrm{mg} \cdot \mathrm{dm}^{-3}$; below this level fruit yield response to $\mathrm{P}$ is significant.

Phosphorus supply promoted consistent effects on fruit quality of both orange varieties. Juice content and acidity varied significantly with increased $\mathrm{P}$ rates (tables I, II). The increase in the total yield of soluble solids per area was related to the nutrient 
availability in the soil. In low soil P (Matão), the increment in solids per area varied from (2411 to 2738 ) $\mathrm{kg} \cdot \mathrm{ha}^{-1}$ with rates of P varying from 9 to $63 \mathrm{~kg} \cdot \mathrm{ha}^{-1}$, whereas in high soil P (Pirassununga), these same rates promoted a decrease in total yield of solids from (2324 to 2282 ) $\mathrm{kg} \cdot \mathrm{ha}^{-1}$.

\subsection{Potassium effects}

Similarly to $\mathrm{P}$, the effects of $\mathrm{K}$ fertilization on orange yield occurred according to the availability of soil exchangeable K. A linear significant response was observed for $\mathrm{K}$ rates in all years in Pirassununga (exchangeable-K $=1.2 \mathrm{mmol}_{\mathrm{C}} \cdot \mathrm{dm}^{-3}$ at $0-20 \mathrm{~cm}$ depth layer), where a 16\% increase in fruit yield occurred as $\mathrm{K}$ rates increased from (25 to 223) $\mathrm{kg} \cdot \mathrm{ha}^{-1}$ (table II). In Matão, where the surface soil is high in exchangeable $\mathrm{K}$ $\left(2.9 \mathrm{mmol}_{\mathrm{C}} \cdot \mathrm{dm}^{-3}\right)$, average fruit yield $\mathrm{did}$ not vary significantly with $\mathrm{K}$ supply during the last four seasons (table III), even though there was a negative effect of $\mathrm{K}$ rates on fruit yield at the beginning of the study. In the last year of fruit yield evaluation, nutrient removal from the soil by fruit harvests diminished the negative effect of $\mathrm{K}$ fertilization on the Valencia grove (data not shown). Potassium removal by fruits is equivalent to (1.5 to 2.0$) \mathrm{kg} \cdot \mathrm{t}^{-1}$, which quantity is comparable with the $\mathrm{N}$ exported by fruit harvest and much greater than other nutrients [13, 29].

Furthermore, excess $\mathrm{K}$ imbalances $\mathrm{Ca}$ and $\mathrm{Mg}$ uptake and impairs vegetative growth of trees, with consequent reduction of fruit yield [30].

Contrary to $\mathrm{P}$ fertilization, response of citrus to $\mathrm{K}$ has been very frequent $[4,7,10]$ and the extent of the response depends on fruit load $[8,31]$

Potassium markedly affected fruit size, which increased with increasing $\mathrm{K}$ fertilization rates (tables I, II). Fruits of Valencia in Matão were heavy (> $210 \mathrm{~g}$ ) for all treatments, which can be attributed to the high soil exchangeable $\mathrm{K}$ content verified at the beginning of the experiment; in this case, maximum fruit mass was attained with $\mathrm{K}$ rates above $225 \mathrm{~kg} \cdot \mathrm{ha}^{-1}$. Variation in fruit size was greater for Pêra in Pirassununga

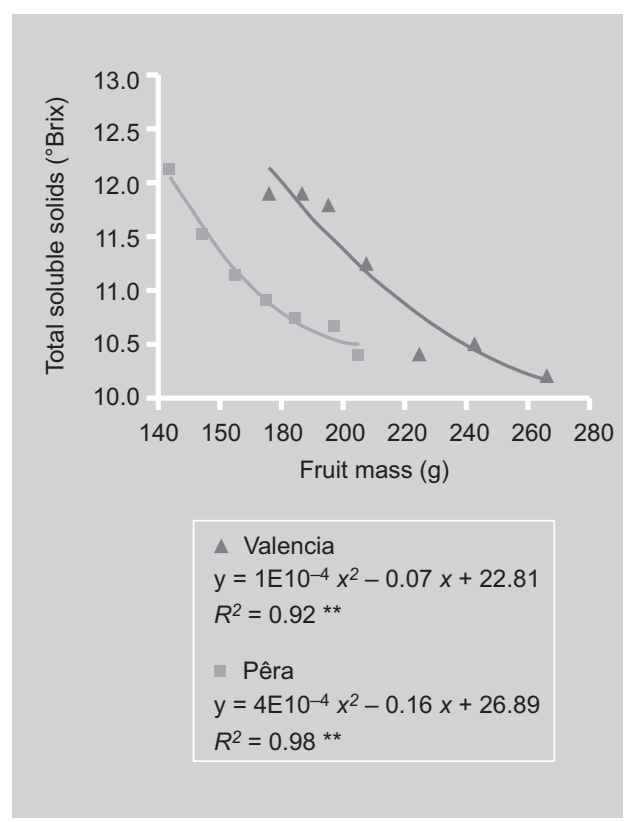

Figure 1.

Relationship between fruit size and total soluble solids in fruits of two sweet orange varieties, Valencia and Pêra (Brazil). Data for fruit size classes were pooled over four seasons.

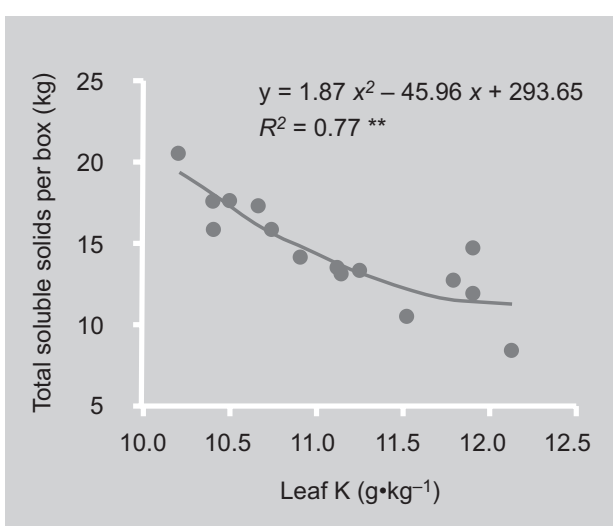

Figure 2.

Production of total soluble solids per box of $40.8 \mathrm{~kg}$, related to $\mathrm{K}$ concentration in the leaves of Pêra and Valencia orange varieties (Brazil). across the $\mathrm{K}$ rates tested. Another study has demonstrated the effects of K supply on size and peel thickness of lemon fruits [11]. This might explain the observed reduction in juice and TSS content of the fruits (tables I, II).

Production of TSS per box $(40.8 \mathrm{~kg}$ ) of fruits was well correlated with leaf $\mathrm{K}$ concentration for both varieties (figure 2). The data obtained suggest that levels of foliar $\mathrm{K}$ above $12 \mathrm{~g} \cdot \mathrm{kg}^{-1}$ caused a significant decrease in internal fruit characteristics for frozen concentrate orange juice processing. Since the industry seeks fruit with high TSS content to optimize production of concentrated juice at $66^{\circ} \mathrm{Brix}$, the nutritional status of 
trees might be used as a diagnostic criterion for nutrient management of citrus groves.

\subsection{Nutrient rates for optimum fruit quality}

Rates for maximum soluble solids production, estimated based on response models established for both experimental sites (table IV), varied significantly, indicating the effects of nutrient supply. Nutrient requirements for maximum production of TSS per box and TSS per hectare contrasted significantly.

Potassium rates for optimizing fruit mass were greater than required for maximum fruit yield in both sites. In Matão, where yield of Valencia was dependent on $\mathrm{N}$ and $\mathrm{P}$ supply, TSS per hectare was maximized at the rates $\left(\mathrm{N}=185 \mathrm{~kg} \cdot \mathrm{ha}^{-1}\right.$ and $\mathrm{P}=$ $40 \mathrm{~kg} \cdot \mathrm{ha}^{-1}$ ) and differed from those required for optimum production of TSS per box $\left(\mathrm{N}=100 \mathrm{~kg} \cdot \mathrm{ha}^{-1}\right.$ and $\left.\mathrm{P}=81 \mathrm{~kg} \cdot \mathrm{ha}^{-1}\right)$. Total production of soluble solids per area depends on fruit yield and variations in fruit size and internal fruit characteristics.

In Pirassununga, where response of Pêra was dependent on $\mathrm{N}$ and $\mathrm{K}$, optimum production of TSS per box was observed at N > $240 \mathrm{~kg} \cdot \mathrm{ha}^{-1}$, whereas TSS produced per area was maximized at the lower $\mathrm{N}$ rate of $174 \mathrm{~kg} \cdot \mathrm{ha}^{-1}$ due to the negative effect of $\mathrm{N}$ rates on juice content and total soluble solids.

The data presented are in agreement with those reported by Du Plessis and Koen [10], in whose study maximum fruit yield of orange trees was attained at $\mathrm{N}=225 \mathrm{~kg} \cdot \mathrm{ha}^{-1}$ and $\mathrm{K}=310 \mathrm{~kg} \cdot \mathrm{ha}^{-1}$. On the other hand, superior fruit size for the fresh market was observed at the lower $\mathrm{N}$ rate of $45 \mathrm{~kg} \cdot \mathrm{ha}^{-1}$. Increased $\mathrm{K}$ rates were also necessary to maximize fruit size of lemon and orange varieties in the field [11, 32].

The results show that the best citrus nutritional program depends on the fruit destination. In general, the external fruit characteristics, such as size, color and rind coarseness, are more important for the fresh fruit market; this is normally obtained, respectively, with lower $\mathrm{N}$ and higher rates of $\mathrm{K}$ than those for fruits for frozen concen- trate orange juice processing. Besides, soil testing and leaf analysis play an important role in defining fruit quality parameters for citrus trees. The mathematical models (table IV) are important tools for estimating optimum N, P and K rates that optimize recommendations for citrus fertilization, focusing on fruits for either the fresh or frozen concentrate orange juice processing markets.

\section{Acknowledgements}

The research presented in this article was achieved thanks to a grant from $\mathrm{CNPq}$ (Brazil).

\section{References}

[1] Spiegel-Roy P., Goldschmidt E.E., Biology of citrus, Camb. Univ. Press, Cambridge, UK, 1996.

[2] Stewart I., Leonard C.D., Wander I.W., Comparison of nitrogen and sources for pineapple oranges, Proc. Fla. State Hortic. Soc. 74 (1961) 75-86.

[3] Stewart I., Wheaton T.A., A nitrogen source and rate study on 'Valencia' oranges, Proc. Fla. State Hortic. Soc. 78 (1965) 22-25.

[4] Koo R.C.J., The influence of N, K and irrigation on tree size and fruit production of 'Valencia' orange, Proc. Fla. State Hortic. Soc. 92 (1979) 10-13.

[5] Reitz H.J., Koo R.C.J., Effect of nitrogen and potassium fertilization on yield, fruit quality and leaf analysis of 'Valencia' oranges, Proc. Am. Soc. Hortic. Sci. 75 (1960) 244-252.

[6] Smith P.F., Scuder G.K., Hrnciar G., A comparison of nitrogen sources, rates and placement on performance of 'Pineapple' orange trees, Proc. Fla. State Hortic. Soc. 81 (1968) 25-29.

[7] Deszyck E.J., Koo R.C.J., Ting S., Effect of potash on yield and quality of Hamlin and Valencia oranges, Proc. Soil Crop Sci. Soc. Fla. 18 (1958) 129-135.

[8] Reese R.L., Koo R.C.J., N and K fertilization effects on leaf analysis, tree size, and yield of three major Florida orange cultivars, J. Am. Soc. Hortic. Sci. 100 (1975) 195-198. 
[9] Reese R.L., Koo R.C.J., Effects of $\mathrm{N}$ and $\mathrm{K}$ fertilization on internal and external fruit quality of three major Florida orange Varieties, J. Am. Soc. Hortic. Sci. 100 (1975) 425428.

[10] Du Plessis S.F., Koen T.J., Effect of nutrition on fruit size of citrus, Proc. Int. Soc. Citric. 1 (1984) 148-150.

[11] Quaggio J.A., Mattos D. Jr., Cantarella H., Almeida E.L.E., Cardoso S.A.B., Lemon yield and fruit quality affected by NPK fertilization, Sci. Hortic. 96 (2002) 151-162.

[12] Cantarella H., Mattos D. Jr., Quaggio J.A., Rigolin A.T., Fruit yield of Valencia sweet orange fertilized with different $\mathrm{N}$ sources and the loss of applied N, Nutr. Cycl. Agroecosyst. 67 (2003) 215-223.

[13] Mattos Jr. D., Quaggio J.A., Cantarella H., Alva A.K., Nutrient content of biomass components of Hamlin sweet orange trees [Citrus sinensis (L.) Osb.], Sci. Agric. 60 (2003) 155-160.

[14] Smith P.F., Scudder G.K. Jr., Hrnciar G., Twenty years of differential phosphate application on pineapple oranges, Proc. Fla. State Hortic. Soc. 76 (1963) 7-12.

[15] Anderson C.A., Effects of phosphate fertilizer on yield and quality of 'Valencia' oranges, Proc. Fla. State Hortic. Soc. 79 (1966) 36-40.

[16] Quaggio J.A., Cantarella H., Raij B. van, Phosphorus and potassium soil test and nitrogen leaf analysis as a base for citrus fertilization, Nutr. Cycl. Agroecosyst. 52 (1998) 67-74.

[17] Colwell, J.D., Computations for studies of soil fertility and fertilizer requirements, Commonw. Agric. Bur., London, UK, 1978.

[18] Andrade D.F., Noleto A.Q., Exemplos de fatorials fracionados $(1 / 2) 4^{3}$ e $(1 / 4) 4^{4}$ para ajuste de modelos polinomiais quadráticos, Pesqui. Agropecu. Bras. 21 (1986) 677-680.

[19] Redd J.B., Hendrix C.M. Jr., Hendrix D.L., Quality control manual for citrus processing plants, v.1, Intercit (Ed.), Fla, USA, 1986.

[20] Raij B. van, Andrade J.C., Cantarella H., Quaggio J.A., Análise química para avaliação da fertilidade de solos tropicais, Inst. Agron., Campinas, Brazil, 2001.
[21] Bataglia O.C., Furlani A.M.C., Teixeira J.P.F., Furlani P.R., Gallo J.R., Métodos de análise químicas de plantas, Inst. Agron., Bol. Téc. 78, Campinas, Brazil, 1983.

[22] Mattos D. Jr., Citrus response functions to N, $\mathrm{P}$, and $\mathrm{K}$ fertilization and $\mathrm{N}$ uptake dynamics, Univ. Fla, Ph.D, Gainesville FL, USA, 2000, $133 \mathrm{p}$.

[23] Quaggio J.A., Mattos D. Jr., Cantarella H., Stuchi E.S., Sempionato O.R., Sweet orange trees grafted on selected rootstocks fertilized with nitrogen, phosphorus and potassium, Pesqui. Agropecu. Bras. 39 (2004) 1-6.

[24] Davies F.S., Albrigo L.G., Citrus, CAB Int., Wallingford, UK, 1994, $254 \mathrm{p}$.

[25] Goldschmidt E.E., Monselise S.P., Physiological assumptions toward the development of citrus fruiting model, Proc. Int. Soc. Citric. 2 (1978) 668-672.

[26] Smith P.F., Citrus nutrition, in: Childers N.F. (Ed.), Temperate to tropical fruit nutrition, 2nd ed., Somerset Press, Somerville, USA, 1966.

[27] Anderson C.A., Effects on phosphate fertilizer on yield and quality of 'Valencia' oranges, Proc. Fla. Sta. Hortic. Soc. 79 (1966) 36-40.

[28] Sobral L.F., Souza L.F.S., Magalhães A.F.J., Silva J.U.B., Leal M.L.S., Response of orange trees to nitrogen, phosphorus and potassium fertilization in a yellow latosol of the Coastal Plateau, Pesquisa Agropecuária Brasileira 35 (2000) 307-312.

[29] Alva A.K., Paramasivam S., An evaluation of nutrient removal by citrus fruit, Proc. Fla. Sta. Hort. Soc. 111 (1999) 126-128.

[30] Mattos D. Jr., Quaggio J.A., Cantarella H., Carvalho S., Superficies de resposta do tangor 'Murcott' a fertilizacao com N, P e K., Rev. Brasil. Frutic. 26 (2004) 164-167.

[31] Cantarella H., Quaggio J.A., Bataglia O.C., Raij B. van, Response of citrus to NPK fertilization in a network of field trials in São Paulo State, Brazil, Proc. Int. Soc. Citric. 2 (1992) 607-612.

[32] Hearn C.J., The influence of cultivar and high nitrogen and potassium fertilization on fruit quality traits of young orange trees, Proc. Fla. Sta. Hortic. Soc. 106 (1993) 8-12. 


\section{Efectos de la fertilización de nitrato, fósforo y potasio en el rendimiento y en la calidad de naranjas producidas en suelos tropicales.}

Resumen - Introducción. El objetivo de nuestros trabajos fue evaluar los efectos de N, P $\mathrm{Y} \mathrm{K}$, así como sus respectivas interacciones en el rendimiento y en la calidad de los frutos de dos variedades de naranjos, Valencia y Pêra, desarrollados en suelos tropicales en el estado de São Paulo, en Brasil, durante cuatro estaciones de producción. Material y métodos. Dos tipos de experimentos se llevaron a cabo según un plan factorial parcial de tipo $1 / 2(4 \times 4 \times 4)$, con cuatro dosis de $\mathrm{N}\left[(30,100,170\right.$ y 240$\left.) \mathrm{kg} \cdot \mathrm{ha}^{-1} \cdot \mathrm{anno}^{-1}\right], \mathrm{P}\left[(9,27,45 \mathrm{y} 63) \mathrm{kg} \cdot \mathrm{ha}^{-1} \cdot \mathrm{año}^{-1}\right.$ ] y $\mathrm{K}\left[(24,91,158\right.$ y 225$\left.) \mathrm{kg} \cdot \mathrm{ha}^{-1} \cdot \mathrm{anno}^{-1}\right]$ aplicadas en la superficie del suelo durante lą estación de lluvias. Se adaptaron funciones de tipo $y=b_{0}+b_{11} \mathrm{~N}+b_{11} \mathrm{~N}^{2}+b_{2} \mathrm{P}+b_{22} \mathrm{P}^{2}+b_{3} \mathrm{~K}+$ $b_{33} \mathrm{~K}+b_{12} \mathrm{NP}+b_{13} \mathrm{NK}+b_{23} \mathrm{PK}$ a variables dependientes: rendimiento y masa del fruto, contennido en jugo, contenido en sólidos solubles totales y en acidez. Resultados. Los mejores rendimientos de Pêra y de Valencia se alcanzaron con dosis respectivas de (189 y 193) kg $\mathrm{N} \cdot \mathrm{ha}^{-1}$. Para esta misma variable, la respuesta a la fertilización de estos dos cultivares con P y $\mathrm{K}$ dependió de la disponibilidad de elementos nutritivos de suelo. El calibre de los frutos de Valencia fue claramente afectado por dosis de $\mathrm{K}$ superiores a $225 \mathrm{~kg} \cdot \mathrm{ha}^{-1}$. El rendimiento de sólidos solubles por caja de frutos $(40.8 \mathrm{~kg}$ ) disminuyó a la vez que el contenido de $\mathrm{K}$ de las hojas variaba de (10 a 12) $\mathrm{g} \cdot \mathrm{kg}^{-1}$. Conclusión. Los análisis de los suelos y de las hojas tienen un papel determinante en la definición del rendimiento y de la calidad de las plantas cítricas. Los programas nutricionales óptimos pueden variar dependiendo de si la cosecha está destinada a la industria del zumo o si está destinada al mercado del fruto fresco.

Brasil / Citrus sinensis / necesidades de nutrientes / aplicación de abonos / dosis de aplicación / rendimiento / calidad / frutas 